\section{THREE HUNDRED TACKLE DENTAL DIFFICULTIES}

Three hundred people attended the 13th annual Premier Symposium at the Shaw Theatre at the Pullman St Pancras in London in November. The event is one of the largest dental risk management events of its kind in the UK.

Professor Tara Renton opened the conference by discussing the 'difficult extraction' and how to anticipate and manage complications in oral

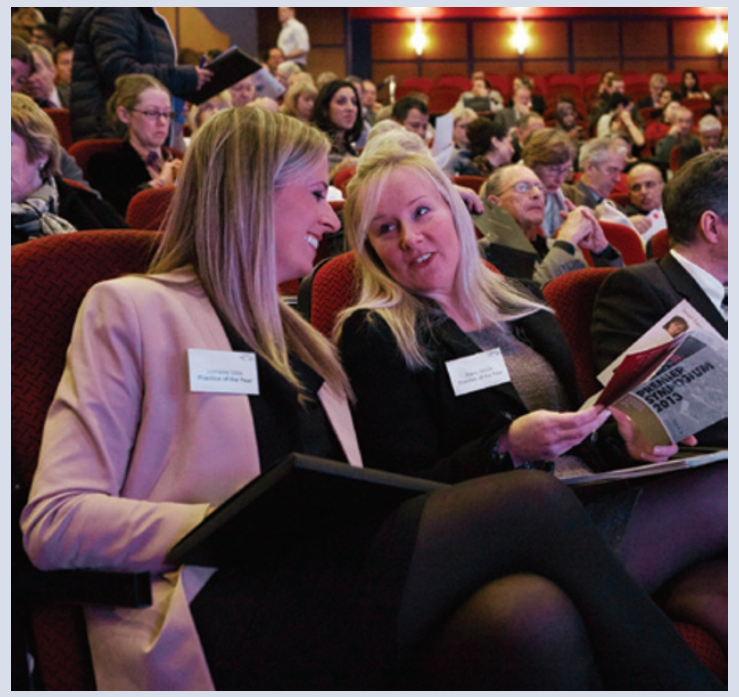

surgery. This was followed by Howard Lloyd who examined the 'difficult root canal' and the potential risks and complications in endodontics.

Professor Andrew Smith considered the facts and fictions behind water line contamination and the risks from prions and vCJD.

Professor Crispian Scully explored the oral manifestations of new and emerging conditions, and provided a guided tour of normal and abnormal oral mucosa.

Dr Kevin Lewis, Dental Director of Dental Protection, who organise the event with schülke, said: 'The continuing success of the Premier Symposium is based on the calibre of speakers and relevance of the topics to our audience'.

\title{
DENTISTS ENCOURAGED TO SUPPORT FOSTERED CHILDREN
}

Scottish dentists are being encouraged to contribute to a new campaign which aims to ensure the wellbeing of children being cared for within private fostering arrangements.

Private fostering is when a parent arranges for a child under 16 to be looked after by an adult who is not a close relative or an approved foster carer for more than 28 days. It may include stepping in to look after a child for a friend who is unwell; agreeing to care for a child from overseas who is studying in Scotland; or con-

tinuing to

care for the child of a partner after separation or bereavement.

The Be Safe, Be Sure campaign aims to improve understanding of private fostering and increase notifications of private fostering arrangements to protect the wellbeing of children who are not officially accounted for through the current system.

Minister for Children and Young People, Aileen Campbell, said: 'The campaign is another step in our efforts to get it right for every child and make sure that every family has the support it needs to thrive'.

Parents or carers involved in private fostering have a legal responsibility to inform local authorities. It is thought that families and carers may not be notifying professionals or agencies simply because they are not aware they are obliged to do so.

Once notified of a private fostering arrangement, local social workers carry out a series of assessments to determine the suitability of the placement.

Doctors, teachers, social workers, dentists, police officers and those working for children's charities will receive leaflets telling them about where to access the new contact information to pass onto parents and private foster carers.

To find out more visit www.scotland.gov.uk/ privatefostering.

\section{DIARY}

Essences of Anterior Implant Aesthetics: The Perio-Ortho-Restorative Connection (1996-2014)

Date: 18 January 2014 Telephone: 02084875555 www.adi.org.uk/janmasterclass2014

BDA Seminar: White, whiter, whitest: successful strategies for predictable teeth whitening Date: 31 January 2014 Venue: BDA, Wimpole Street, London

Email: events@bda.org Telephone: 02075634590 www.bda.org/seminars

Oral-B Up To Date seminar Date and location: 13 February 2014, Bristol; 27 February 2014, Plymouth; 13 March 2014, Warrington; 27 March 2014, Newcastle

Telephone: 07585508550 Email: julia@ab-communications. com

www.dentalcare.com

IDEM Singapore - International Dental Exhibition and Meeting Date: 3-6 April 2014

Venue: SUNTEC Convention and Exhibition Centre, Singapore www.idem-singapore.com

British Dental Conference At Exhibition 2014 Date: 10-12 April 2014 Venue: Manchester Central Convention Complex, Manchester www.bda.org/conference

Clinical Innovations

Conference 2014

Date: 14-15 May 2014

Venue: Kings Place,

King's Cross, London

Telephone: 02074008989

Email:info@healthcare-

learning.com 